\title{
Research Designs and Methodologies of Studies in Student Self-Assessment: A Content Analysis
}

\author{
Maria Darra \\ Department of Primary Education, University of the Aegean \\ Dimokratias 1, Rhodes, 85132, Greece \\ Tel: 30-693-242-5804 E-mail: darra@aegean.gr \\ Anastasia Papanthymou (Corresponding author) \\ Department of Primary Education, University of the Aegean \\ Dimokratias 1, Rhodes, 85132, Greece \\ Tel: 30-694-833-9499Ｅ-mail: an2005pap@hotmail.com
}

\author{
Received: June 14, $2019 \quad$ Accepted: Oct. 3, $2019 \quad$ Published: November 1, 2019 \\ doi:10.5296/jse.v9i4.15438 URL: https://doi.org/10.5296/jse.v9i4.15438
}

\begin{abstract}
The purpose of this paper is to analyze the content of 33 empirical studies related to student self-assessment in primary and secondary education and have been published over the last decade (2009-2019) in 19 scientific journals classified in Scimago (only articles in journals with peer review system to assure their quality) in order to investigate: a) the research design (experimental, quasi-experimental, non-experimental), b) the research method (mixed method, quantitative method, qualitative method), c) the specific design (pretest-posttest etc.), d) the data collection method (questionnaire, interviews, etc.). According to the main findings most studies use non-experimental design, followed by experimental and quasi-experimental design. With regard to research methods quantitative method is used in all research designs, while qualitative and mixed method are used to a lesser degree and only in experimental and non-experimental design. Regarding the specific design, most experimental and quasiexperimental studies adopt a "pretest-posttest" design, while non-experimental studies follow mainly descriptive design. Finally, concerning the data collection methods, questionnaire is the most common method for all research designs, as opposed to other methods, such as interview or the combination of questionnaire and interview. Therefore, there is a need to investigate the issue of student self-assessment using experimental or quasi-experimental
\end{abstract}




\section{Macrothink

research design where the mixed methodological approach will be adopted and data collection will be carried out using various research tools such as the interview and the questionnaire in order to triangulate the results.

Keywords: student self-assessment, method, research design, primary education, secondary education 


\section{Introduction}

Student assessment as a present and ongoing procedure in the school system is very significant for students, family, school and society (Gashi-Shatri \& Zabeli, 2018). Assessment in education is for formative and summative purposes. Particularly, for students, assessment is used to motivate them, improve their future performance, differentiate their learning opportunities, provide feedback to them, identify their strengths and weaknesses, and direct students' choices of their professional careers (Wong, 2017).

The need to improve student assessment has become imperative and this has led to find new ways of assessing student performance, as there are many who criticize and identify weaknesses in traditional assessment (Papageorgiou, 2017). These new ways of assessment constitute the authentic assessment. The characteristic of authentic assessment is the students' involvement in the assessment procedure by using authentic elements of learning procedures and outcomes (Chang, Tseng, \& Lou, 2012) and this involvement or participation in assessment has various benefits for students such as the development of learning skills, the improvement of performance, the enhancement of transferable skills and the positive affective and emotional impact (Tai, 2012).

Self-assessment is a form of authentic assessment with significant benefits for students. Among these are the fact that self-assessment helps students become more independent, recognize the next steps in their learning, (Gashi-Shatri \& Zabeli, 2018), identify gaps in their understanding, become self-regulating and reflective learners (Johnson \& Winterbottom, 2011), while simultaneously self-assessment affects their motivation (Johnson \& Winterbottom, 2011; Gashi-Shatri \& Zabeli, 2018).

Despite the fact that there are a lot of studies that examine the issue of student self-assessment, there are not many studies that have investigated the research design and methods that have been adopted in order to collect useful information that will help future researchers study this particular form of authentic assessment.

Specifically, in the context of higher education, Pastore's research (2017) was carried out. It was a content analysis that aimed at studying the research design and methods used in studies that examine student self-assessment in higher education within the European area. According to the main findings, non-experimental design is the most commonly used. Furthermore, it was found that quasi-experimental design is not used, while experimental design is rarely used. In addition, it has been found that the emphasis on exclusively quantitative or qualitative methods is a limitation in the research field of higher education.

In addition, according to Harris and Brown (2018) interventions designed to improve teachers' use of self-assessment have found models based on action research principles to be very useful. Analytically, teachers first learn the practices and then develop their own action plans on how self-assessment will be integrated into their teaching. Subsequently, teachers monitor the implementation, gather data concerning efficacy, and think about weaknesses and strengths to make the necessary improvements in following implementations.

Moreover, Wong (2016) that examined students' and teachers' perceptions on students' 
self-assessment ability in primary education in Singapore, concerning data collection methods she noticed that most of the research does not use data from interviews with teachers and students that could provide a richer analysis of students' ability and she underlined the need to triangulate the results from qualitative and quantitative sources of data.

The present study intends to investigate the issue of student self-assessment in primary and secondary education in terms of research design and methods used internationally over the last decade (2009-2019), and it uses a content analysis similar to Pastore's (2017). This study consists of the following sections: a) theoretical framework, c) purpose of the study and research questions, d) results, e) discussion, f) conclusions, and g) limitations and suggestions for further research.

\section{Theoretical Framework}

According to Panadero and Alonso-Tapia (2013) self-assessment is the qualitative assessment of the learning procedure and of its final product based on predefined criteria and it doesn't focus on the score but in the understanding of the procedures by learners through which they can learn from their mistakes and achievements. It is therefore a procedure of reflection. It is a dynamic technique where students assess the quality of their work on the basis of criteria so that they can learn to work even better in the future (Ross, Hogaboam-Gray, \& Rolheiser, 2002), or as Andrade (2008) states during the process of self-assessment, students reflect on the quality of their work and assess the degree to which their work meets the criteria or the goals.

Specifically, self-assessment is more precisely defined as a procedure where students: a) monitor and assess the quality of their behavior and thought during their learning, and $b$ ) identify strategies that can help them improve their understanding and skills. Namely, self-assessment occurs when students judge their work in order to improve their performance, as they identify discrepancies between current and desired performance and this aspect of self-assessment is closely aligned with educational standards, which provides clear criteria and goals that can make the process of student self-assessment easier (McMillan \& Hearn, 2008).

Andrade and Cizek (2010) note that although even young students are usually able to reflect on the quality of their work, they do not always do so. This is because one or more of the following required conditions are not present. In particular, in order to have effective self-assessment, students need a. realization of the value of the procedure of self-assessment, b. access to clear criteria, c. a specific performance or task for assessment, d. self-assessment models, e. guidance and help with the process of self-assessment procedure, including feedback, f. practice, g. indications with regard to when it is appropriate to self-assess and $h$. favorable circumstances to revise and improve performance or task. Although the above list of conditions might seem prohibitive, the process of self-assessment is achievable and it has been implemented in many schools around the world.

\section{Purpose of the Study and Research Questions}

The purpose of this paper is to analyze the content of 33 empirical studies related to student 


\section{Macrothink}

self-assessment in primary and secondary education and have been published over the last decade (2009-2019) in 19 scientific journals classified in Scimago (only articles in journals with peer review system to assure their quality) in order to investigate the research design and methods of these studies that examine the issue of student self-assessment in primary and secondary education.

In particular, this paper aims to answer the following research questions:

a) what research design is used (experimental, quasi-experimental, non-experimental)?

b) what research method is the most commonly used (mixed method, quantitative method, qualitative method)?

c) what specific design is used (pretest-posttest, etc.)?

d) what data collection method is used (questionnaire, interviews, etc.)?

\section{Methodology}

The studies that were reviewed, were identified in articles selected on the basis of the following criteria: a) they are included in Scimago journals and are peer review to assure high quality of articles, b) they have been published over the last decade (2009-2019) and c) examine the issue of self-assessment empirically at primary and /or secondary education internationally. Therefore, theoretical studies or literature reviews were not included. Table 1 shows the list of journals and their ISSN. 


\section{MlMacrothink}

Table 1. List of journals

\begin{tabular}{lll}
\hline & Journal Title & ISSN \\
\hline 1 & Asia-Pacific Education Researcher & $0119-5646$ \\
2 & Assessment in Education: Principles, Policy \& Practice & $0969-594 X, 1465-329 X$ \\
3 & Australian Educational Researcher & $0311-6999$ \\
4 & British Journal of Religious Education & $1740-7931,0141-6200$ \\
5 & Early Childhood Education Journal & $1082-3301$ \\
6 & Education 3-13: International Journal of Primary, Elementary & $1475-7575,0300-4279$ \\
& and Early Years Education & \\
7 & Educational Psychology & $1469-5820,0144-3410$ \\
8 & Educational Studies & $0305-5698,1465-3400$ \\
9 & Innovations in Education and Teaching International & $1470-3297,1470-3300$ \\
10 & Instructional Science & $0020-4277$ \\
11 & International Journal of Educational Research & $0883-0355$ \\
12 & International Journal of Instruction & $1694609 \mathrm{X}, 13081470$ \\
13 & Irish Educational Studies & 17474965,03323315 \\
14 & Journal of Social Studies Education Research & $1309-9108$ \\
15 & Pedagogies: An International Journal & $1554-480 \mathrm{X}$ \\
16 & Procedia - Social and Behavioral Sciences & $0000-2009,0000-2012$ \\
17 & Reading and Writing & $0922-4777,1573-0905$ \\
18 & Reading Psychology & $0270-2711,1521-0685$ \\
19 & The Journal of Educational Research & $19400675,0022-0671$ \\
\hline
\end{tabular}

Specifically, 33 studies from a total of 19 journals were identified and were examined in terms of research design and methods. Using content analysis, codes and cross-tabulation tables were created. The methodological approach that present study used was similar to that adopted by Pastore (2017) who explored the same issue in higher education in Europe.

Firstly, a general categorization of studies for research design (experimental, quasi-experimental or non-experimental) was created. Secondly, another general categorization based on the research methods (mixed method, quantitative method, qualitative method) was also created. Consequently, a more specific categorization for research design that included the specific design (posttest only, pretest-posttest etc.) was created. Furthermore, a more specific categorization of research methods was developed, which included specific data collection methods such as questionnaire, interview, etc. Therefore, research designs and methods were coded from a general to a more specific level.

\section{Results}

Table 2 presents the research design that was adopted by studies that examine the issue of student self-assessment in primary and secondary education. In particular, table 1 shows the outcome of the first codification of the studies into experimental, quasi-experimental and non-experimental studies. 


\section{$\triangle$ Macrothink}

Journal of Studies in Education

ISSN 2162-6952

Table 2. Research design used in student self-assessment studies in primary and secondary education

Research Design

\section{Journal Title}

Asia-Pacific Education Researcher

Assessment in Education: Principles, Policy \& Practice

Australian Educational Researcher

British Journal of Religious Education

Early Childhood Education Journal

Education 3-13

Educational Psychology

Educational Studies

Innovations in Education and Teaching International

Instructional Science

International Journal of Educational Research

International Journal of Instruction

Irish Educational Studies

Journal of Social Studies Education Research

Pedagogies: An International Journal

Procedia - Social and Behavioral Sciences

Reading and Writing

Reading Psychology

The Journal of Educational Research

Experimental Quasi-experimental Non-experimental

Row Total

1
1
0
0
1
0
1
0
1
2
1
1
0
0
0
0
0
0
1
10

0
0
0
0
0
0
1
0
0
1
0
0
0
0
1
0
1
0
1
5

12

34

$1-1$

$1-1$

0

$3 \quad 3$

02

1

0

$0 \quad 3$

23

12

$1-1$

1 1

0 1

22

0 1

1 1

02

$18 \quad 33$

Table 3 presents the research methods (mixed methods, quantitative methods, qualitative methods) used in each type of design (experimental, quasi-experimental, non-experimental).

Table 3. Research methods used in student self-assessment studies in primary and secondary education based on the type of design

\begin{tabular}{lcccc}
\hline Type of Design & Mixed Methods & $\begin{array}{c}\text { Research Methods } \\
\text { Quantitative Methods }\end{array}$ & Qualitative Methods & Row Total \\
\hline Experimental & $\mathrm{n}=2(29 \% ; 20 \%)^{*}$ & $\mathrm{n}=7(33 \% ; 70 \%)$ & $\mathrm{n}=1(20 \% ; 10 \%)$ & 10 \\
Quasi-experimental & $\mathrm{n}=0(0 \% ; 0 \%)$ & $\mathrm{n}=5(24 \% ; 100 \%)$ & $\mathrm{n}=0(0 \% ; 0 \%)$ & 5 \\
Non-experimental & $\mathrm{n}=5(71 \% ; 28 \%)$ & $\mathrm{n}=9(43 \% ; 50 \%)$ & $\mathrm{n}=4(80 \% ; 22 \%)$ & 18 \\
Column Total & 7 & 21 & 5 & 33 \\
\hline
\end{tabular}

Note: Cells that have two percentages in parentheses, the percentage on the left is the percentage of the column and the percentage on the right is the percentage of the row.

Table 4 shows the specific design (posttest only, pretest-posttest, etc.) used in each type of design (experimental, quasi-experimental, non-experimental). 
Table 4. Specific design used in student self-assessment studies in primary and secondary education based on type of design

\begin{tabular}{llccc}
\hline Specific Design & Experimental & $\begin{array}{l}\text { Type of Design } \\
\text { Quasi-experimental }\end{array}$ & Non-experimental & Row Total \\
\hline $\begin{array}{l}\text { Posttest only } \\
\text { Pretest-Posttest/First }\end{array}$ & $\mathrm{n}=1(10 \% ; 100 \%)$ & $\mathrm{n}=0(0 \% ; 0 \%)$ & $\mathrm{n}=0(0 \% ; 0 \%)$ & 1 \\
draft-Final draft & $\mathrm{n}=7(70 \% ; 64 \%)$ & $\mathrm{n}=4(80 \% ; 36 \%)$ & $\mathrm{n}=0(0 \% ; 0 \%)$ & 11 \\
Descriptive & $\mathrm{n}=0(0 \% ; 0 \%)$ & $\mathrm{n}=0(0 \% ; 0 \%)$ & $\mathrm{n}=10(56 \% ; 100 \%)$ & 10 \\
A priori content analysis & $\mathrm{n}=0(0 \% ; 0 \%)$ & $\mathrm{n}=0(0 \% ; 0 \%)$ & $\mathrm{n}=1(5 \% ; 100 \%)$ & 1 \\
Sequential explanatory mixed & $\mathrm{n}=0(0 \% ; 0 \%)$ & $\mathrm{n}=0(0 \% ; 0 \%)$ & $\mathrm{n}=1(5 \% ; 100 \%)$ & 1 \\
Cross-sectional & $\mathrm{n}=0(0 \% ; 0 \%)$ & $\mathrm{n}=0(0 \% ; 0 \%)$ & $\mathrm{n}=2(11 \% ; 100 \%)$ & 2 \\
Practitioner research & $\mathrm{n}=0(0 \% ; 0 \%)$ & $\mathrm{n}=0(0 \% ; 0 \%)$ & $\mathrm{n}=1(5 \% ; 100 \%)$ & 1 \\
Longitudinal & $\mathrm{n}=0(0 \% ; 0 \%)$ & $\mathrm{n}=1(20 \% ; 50 \%)$ & $\mathrm{n}=1(5 \% ; 50 \%)$ & 2 \\
Other & $\mathrm{n}=2(20 \% ; 50 \%)$ & $\mathrm{n}=0(0 \% ; 0 \%)$ & $\mathrm{n}=2(11 \% ; 50 \%)$ & 4 \\
Column Total & 10 & 5 & & 18 \\
\hline
\end{tabular}

Note: Cells that have two percentages in parentheses, the percentage on the left is the percentage of the column and the percentage on the right is the percentage of the row.

The "other" category includes designs based on specific models or on self-assessment theories or on proposals regarding self-assessment procedures.

Table 5 shows the data collection method adopted by each type of design.

Table 5. Data collection method used in self-assessment studies in primary and secondary education based on type of design

\begin{tabular}{lcccc}
\hline Data Collection Method & Experimental & $\begin{array}{c}\text { Type of Design } \\
\text { Quasi-experimental }\end{array}$ & Non-experimental & Row Total \\
\hline Questionnaire & $\mathrm{n}=9(90 \% ; 36 \%)$ & $\mathrm{n}=5(100 \% ; 20 \%)$ & $\mathrm{n}=11(61 \% ; 44 \%)$ & 25 \\
Interview & $\mathrm{n}=1(10 \% ; 20 \%)$ & $\mathrm{n}=0(0 \% ; 0 \%)$ & $\mathrm{n}=4(22 \% ; 80 \%)$ & 5 \\
Content analysis of comments & $\mathrm{n}=0(0 \% ; 0 \%)$ & $\mathrm{n}=0(0 \% ; 0 \%)$ & $\mathrm{n}=1(5 \% ; 100 \%)$ & 1 \\
Questionnaire, interview, observation & $\mathrm{n}=0(0 \% ; 0 \%)$ & $\mathrm{n}=0(0 \% ; 0 \%)$ & $\mathrm{n}=2(11 \% ; 100 \%)$ & 2 \\
etc. & & & & 33 \\
Column Total & 10 & 5 & 18 & 33 \\
\hline
\end{tabular}

Note: Cells that have two percentages in parentheses, the percentage on the left is the percentage of the column and the percentage on the right is the percentage of the row.

\section{Discussion}

From the sample of $(\mathrm{N}=33)$ studies that examine the issue of student self-assessment in primary and secondary education and emerged from the sample of $(\mathrm{N}=19)$ scientific journals, most studies $(\mathrm{N}=18)$ follow non-experimental design, less studies $(\mathrm{N}=10)$ follow experimental design and even less studies $(\mathrm{N}=5)$ follow quasi-experimental design. Therefore, non-experimental design is the most commonly used research design and this finding is in line with the findings of a similar study conducted by Pastore (2017) in higher education in 
the European. On the other hand, quasi-experimental design was not found in higher education as noted by Pastore (2017) in contrast to the findings of the present study where quasi-experimental studies are found in primary and secondary education and they are half of the experimental studies and almost a quarter of non-experimental studies. Consequently, a limitation is identified regarding the almost exclusive use of the non-experimental design in primary and secondary education, which is also highlighted by Pastore (2017) for higher education.

With regard to research methods, quantitative method $(\mathrm{N}=21)$ is the most used in all research designs (experimental, quasi-experimental, non-experimental), while mixed method $(\mathrm{N}=7)$ and qualitative method $(\mathrm{N}=5)$ are used to a much lesser degree. Specifically, quantitative methods are used primarily in experimental studies $(\mathrm{N}=7 ; 70 \%)$ and non-experimental studies $(\mathrm{N}=9 ; 50 \%)$ whereas mixed and qualitative methods are used to a lesser extent. Quasi-experimental studies use only quantitative methods ( $=5 ; 100 \%)$. Pastore (2017) notes that in higher education, quantitative methods are also more commonly used. Moreover, there is less use of qualitative research methods while there is no use of mixed research methods and this last finding is in contrast to the findings of the present study where in primary and secondary education all methods are used. It should be noted, that Pastore's (2017) study had a geographical limitation that the present study does not have and the differences observed may be due to that.

Concerning the specific design, most experimental $(\mathrm{N}=7 ; 70 \%)$ and quasi-experimental $(\mathrm{N}=4 ; 80 \%)$ studies adopt the design "pretest -posttest"/"first draft-final draft", while the majority of non-experimental studies $(\mathrm{N}=10 ; 56 \%)$ adopt the descriptive design and to a lesser extent the cross-sectional design $(\mathrm{N}=2 ; 11 \%)$ and the category "other" $(\mathrm{N}=2 ; 11 \%)$ which includes designs based on specific models or on self-assessment theories or on proposals regarding self-assessment procedures. In addition, experimental studies use to a very small extent $(\mathrm{N}=2 ; 20 \%)$ the "other" category and the design "posttest only" $(\mathrm{N}=1 ; 10 \%)$. Moreover, non-experimental studies use equally and to a limited extent specific designs such as the priori content analysis $(\mathrm{N}=1 ; 5 \%)$, the sequential explanatory mixed design $(\mathrm{N}=1 ; 5 \%)$, the practitioner research $(\mathrm{N}=1 ; 5 \%)$ and the longitudinal design $(\mathrm{N}=1 ; 5 \%)$, which is also found in quasi-experimental studies $(\mathrm{N}=1 ; 20 \%)$.

With regard to data collection methods, the questionnaire is the most frequently used method $(\mathrm{N}=25)$ in all research designs, while other methods such as the interview $(\mathrm{N}=5)$, the combination of interviews, observation etc. $(\mathrm{N}=2)$ and, the content analysis of comments $(\mathrm{N}=1)$ are used less. Analytically, experimental studies use the questionnaire more frequently $(\mathrm{N}=9 ; 90 \%)$ than the interview $(\mathrm{N}=1 ; 10 \%)$ while the quasi-experimental studies use only the questionnaire $(\mathrm{N}=5 ; 100 \%)$. Non-experimental studies primarily use the questionnaire $(\mathrm{N}=11 ; 61 \%)$, secondly the interview $(\mathrm{N}=4 ; 22 \%)$ and even less the combination of questionnaire, interview, observation etc. $(\mathrm{N}=2 ; 11 \%)$ and the content analysis of comments $(\mathrm{N}=1 ; 5 \%)$. Although it is noted by researchers such as Wong (2016) the importance of triangulating the data, the collection of data from various sources of quantitative and qualitative nature is not so preferable. 


\section{$\Lambda$ Macrothink}

\section{Conclusion}

The present study is a content analysis that explores the research design and methods used in studies that examine the issue of student self-assessment in primary and secondary education over the last decade (2009-2019).

The research design chosen in the examined studies is mainly non-experimental design and, therefore, there is a need for more experimental design including quasi-experimental design to overcome the limitation imposed by the almost exclusive use of the non-experimental approach in primary and secondary education.

Regarding the research methods, the quantitative method is the one that is chosen mainly in all research designs and therefore special attention should be given to the other methods, such as the qualitative and the mixed research method.

With regard to the specific design, the descriptive design is mainly chosen for non-experimental studies, while experimental and quasi-experimental studies use principally the specific design "pretest -posttest/first draft-final draft". In addition, other specific designs have been used to examine the issue of student self-assessment in primary and secondary education such as longitudinal, explanatory sequential mixed, a priori content analysis, posttest only, practitioner research, as well as designs based on specific models or on self-assessment theories or on proposals concerning self-assessment procedures.

Finally, concerning data collection methods, the questionnaire is the most used tool in all research designs and therefore there is a need to collect data simultaneously from quantitative and qualitative sources.

In conclusion, there is a need to explore the issue of student self-assessment in primary and secondary education using experimental or quasi-experimental research design where the mixed methodological approach will be adopted and data collection will be carried out using various research tools such as the interview and the questionnaire in order to triangulate the results.

\section{Limitations and Suggestions for Further Research}

The present study collected articles from a specific number of journals and this is a limitation. Therefore, a future research could focus on searching articles from a bigger number of scientific journals. In addition, a more specific research on research designs and methods could be done separately for primary and secondary education or even a comparative study including all levels of education could be useful in order to conclude about the methodological approach of the issue of self-assessment per education level.

Finally, it would be interesting to approach the issue of student self-assessment in primary and secondary education using experimental design and triangulation of data from qualitative and quantitative sources.

\section{References}

Andrade, H. (2008). Self-assessment through rubrics. Educational leadership, 65(4), 60-63. 
Available: https://imoberg.com/files/2008_Self-Assessment_through_Rubrics.pdf

Andrade, H., \& Cizek, G. J. (2010). Students as the definitive source of formative assessment: Academic self-assessment and the self-regulation of learning. In Handbook of formative assessment (pp. 102-117). New York: Routledge.

Chang, C. C., Tseng, K. H., \& Lou, S. J. (2012). A comparative analysis of the consistency and difference among teacher-assessment, student self-assessment and peer-assessment in a Web-based portfolio assessment environment for high school students. Computers \& Education, 58(1), 303-320. https://doi.org/10.1016/j.compedu.2011.08.005

Gashi-Shatri, Z. F., \& Zabeli, N. (2018). Perceptions of students and teachers about the forms and student self-assessment activities in the classroom during the formative assessment. Journal of Social Studies Education Research,9(2), 28-46. Available: https://dergipark.org.tr/download/article-file/496753

Harris, L. R., \& Brown, G. T. (2018). Using Self-Assessment to Improve Student Learning. New York: Routledge.

Johnson, N., \& Winterbottom, M. (2011). Supporting girls' motivation in science: a study of peer-and self-assessment in a girls-only class. Educational Studies, 37(4), 391-403. https://doi.org/10.1080/03055698.2010.508605

McMillan, J. H., \& Hearn, J. (2008). Student self-assessment: The key to stronger student motivation and higher achievement. Educational Horizons, 87(1), 40-49. Available: https://files.eric.ed.gov/fulltext/EJ815370.pdf

Panadero, E., \& Alonso-Tapia, J. (2013). Self-assessment: theoretical and practical connotations, when it happens, how is it acquired and what to do to develop it in our students. Electronic Journal of Research in Educational Psycology, 11(2), 551-576. https://doi.org/10.14204/ejrep.30.12200

Papageorgiou, K. A. (2017). Alternative evaluation proposals for primary education. In A. Lionarakis, S. Ioakimidou, M. Niari, G. Manousou, T. Briefcase, S. Papadimitriou, A. Apostolidou (Eds.) 9th International Conference in Open and Distance Learning, November 24-26, 2017, (pp. 150-159). Patra: Hellenic Open University

Pastore, S. (2017). Research Designs and Methods in Self-Assessment Studies: A Content Analysis. International Journal of Evaluation and Research in Education, 6(4), 257-264. https://doi.org/10.11591/ijere.v6i4.8921

Ross, J.A., Hogaboam-Gray, A., \& Rolheiser, C. (2002). Student self-evaluation in grade 5-6 mathematics: Effects on problem-solving achievement. Educational Assessment, 8(1), 43-59. https://doi.org/10.1207/S15326977EA0801_03

Tai, C. (2012). Undergraduate business and management students' experiences of being involved in assessment (Dissertation thesis). Edinburgh: University of Edinburgh.

Wong, H. M. (2016). I can assess myself: Singaporean primary students' and teachers' 


\section{Macrothink}

Journal of Studies in Education

ISSN 2162-6952 2019, Vol. 9, No. 4

perceptions of students' self-assessment ability. Education 3-13: International Journal of Primary, Elementary and Early Years Education 44(4), 442-457. https://doi.org/10.1080/03004279.2014.982672

Wong, H. M. (2017). Implementing self-assessment in Singapore primary schools: effects on students' perceptions of self-assessment. Pedagogies: An International Journal, 12(4), 391-409. https://doi.org/10.1080/1554480X.2017.136234

\section{Copyright Disclaimer}

Copyright for this article is retained by the author(s), with first publication rights granted to the journal.

This is an open-access article distributed under the terms and conditions of the Creative Commons Attribution license (http://creativecommons.org/licenses/by/3.0/). 